\title{
University Branding and Measuring Brand Equity: Conceptual Framework and Empirical Studies
}

\begin{abstract}
In highly competitive marketplace, branding and brand management have become increasingly important as organizations seek competitive advantage. As colleges and universities have faced an increased competition, university administrators have realized that relying only on external marketing and branding efforts are not sufficient strategies for building strong university brands and brand equity. Based on review of literature, this paper presents a summary of a brand ecosystem as conceptual and the results of empirical studies that utilize consumer-based brand equity (CBBE) and brand ecosystem framework to understand university branding and measuring university brand equity. The results of the empirical studies indicate that universities are complex systems of sub-brands, thus, managing these subsystems require consideration of all relevant brand equity dimensions as a holistic way in a brand ecosystem framework showing their direct and indirect relationships in creating a strong university brand and brand equity. These findings offer important insights that could have strategic implications for developing successful university branding strategies.
\end{abstract}

\section{Introduction}

In today's global marketplace, the most distinctive skill of marketers is their ability to build and manage brands (Kotler and Armstrong, 2010). Over the years, brands have served as effective carriers of functional and symbolic information about goods, services, and experiences (Oh et al., 2020). A brand functions as a powerful differentiator for the business and as a decision-making tool for customers. In highly competitive marketplace, branding and brand management have become increasingly important as organizations seek competitive advantage. A powerful brand enjoys a high level of consumer awareness and loyalty (mind share and heart share), and it forms the basis for building strong and profitable customer relationship. The real value of a strong brand is its ability to capture customer preference and loyalty. As a result, recently the concept of brand equity has received vast attention due to the growing nature of competition in domestic and international markets. Brand equity is a key intangible asset (Ambler et al., 2002) that arises from past brand building activities. Since the concept of brand equity is the foundation of any branding strategy, it has become the focus of many branding studies (Rosenbaum-Elliott et al., 2011). All this contributes to an increase of the requirements for the competence of a manager, and especially with regard to their social and emotional intelligence.

Aaker (1991, p.15) defined brand equity as "a set of assets and liabilities linked to a brand, its name, and symbol, which adds or subtracts from the value provided by a product or service to a firm and/or that firm's customers". Keller (1993, p.8), who coined the term customer-based brand equity (CBBE), defined brand equity based as "the differential effect of brand knowledge on consumer response to the marketing of the brand". A brand with strong equity is easily recognized and recalled, and more importantly, creates a distinction strong enough to generate favorable responses towards the brand (Keller, 2013). The consensus is that the value of a brand ultimately 
resides in the minds of consumers; thus, consumers are the real owners of the brands. Consequently, what consumers perceive as the value may differ from what the brand owner intends to offer $(\mathrm{Md}$ Noor et al., 2019). According to Keller (2013), CBBE happens when consumers have high awareness of and familiarity with the brand and have strong, favorable, and unique associations for the brand. Aaker (1991) originally conceptualized brand equity as a multidimensional concept that includes brand awareness, brand associations, perceived quality, and brand loyalty, which are the most used $\mathrm{CBBE}$ dimensions in brand equity research.

\section{University Branding and Brand Equity}

In recent years, experiencing an increase in domestic and international competition, a negative global economic environment, and a decrease in enrollments, colleges and universities have faced an increased competition (Whisman, 2007). As a result, university administrators have realized that relying only on external marketing and branding efforts are not sufficient strategies for building strong university brands and brand equity (Pinar et al., 2014), so they are turning to branding efforts as the relatively simple promotional approaches of the past no longer seem to work. For Higher Education Institutions (HEIs), branding of universities as a recent marketing tool aims to attract, engage, and retain students and position universities (Wilson and Elliot, 2016; Sultan and Wong, 2014). A university brand reflects the university's ability to fulfill students' needs and creates trust in its capacity to deliver the promised services (Nguyen et al. 2016). Also, universities as service organizations depend on their unique service properties to differentiate themselves from the competition. In recent years, different topics related to university branding and university brand equity have been addressed by different studies show the growing interest in branding of HEIs. While the prior studies provide insights into understanding of the specific areas of university branding, they do not capture the holistic effects of the university brand equity dimensions (core and supporting) and the direct and indirect relationships and interactions between the dimensions presented in the brand ecosystem (Pinar et al., 2011).

$\mathrm{Ng}$ and Forbes (2009) suggested a gap model for the university learning experience based on the service quality literature, recognizing the various parties involved in the creation of the experience, including the students themselves. They highlight the complexity of the university experience as it is co-created, emergent, unstructured, interactive, and uncertain, and not all students share the same goals and orientation (academic, personal, vocational, social) with respect to university experience. $\mathrm{Ng}$ and Forbes (2009) proposed a model to capture student university experience that identified core and supporting academic value-creation dimensions. The brand ecosystem framework proposed by Pinar et al. (2011) includes the core and supporting brand equity dimensions of $\mathrm{Ng}$ and Forbes (2009), where academic-student interaction is often an important aspect of learning experience in building university brand. From a strategic perspective, brands can be designed to deliver greater customer value by building a brand ecosystem that includes the value networks and their interactions at each stage of brand value building and delivery. Brand ecosystem is a set of different activities that contribute to building a strong brand that cover all the stages of value creation from initial design idea to the final consumer brand experience (Pinar and Trapp, 2008). The core university brand equity dimensions identified are brand awareness, perceived quality, brand association, brand trust, learning environment, emotional environment, university reputation, and brand loyalty, whereas the supporting university brand equity dimensions identified are library services, dining services, residence hall, and physical facilities.

\section{University CBBE - Empirical Studies}

The brand ecosystem framework for university branding has been used in two empirical studies, where one study in Turkey (Pinar et al., 2020) used only the core university brand equity dimensions and the other study in the United States (Girard and Pinar, 2020a) included both the core and supporting university brand equity dimensions. These studies utilized the CBBE theory and the brand ecosystem framework to develop measurements and tested the relationships between core and supporting brand equity dimensions that are significant and important in building brands of 
universities, and they are valid and reliable measures of the CBBE dimensions of university branding. The results of both studies supported the assertion that universities are complex systems of various sub-brands that require brand management by considering all relevant university brand equity dimensions in a holistic perspective in a brand ecosystem framework (Pinar et al., 2011) with their direct and indirect relationships. These findings indicate that it is essential to have the holistic approach to examining university brand equity to understand and capture the complex bundles of benefits in creating a strong university brand and brand equity. The findings from the U.S. study confirm the assertion by $\mathrm{Ng}$ and Forbes (2009) that the core university brand equity dimensions cannot function properly without the supporting dimensions, as they work together, having direct and indirect effects in an integrated, dynamic way to build the brand in higher education and university brand equity. One of the unexpected findings is that while emotional environment in the U.S. study directly influences brand trust and indirectly brand loyalty, it is directly influenced by other BE dimensions, emotional environment in the Turkish study does not influence the brand trust, university reputation, or brand loyalty, which is interesting for understanding cross-cultural differences.

In another study (Girard and Pinar, 2020b) compared the importance and performance of university brand equity dimensions to determine if any significant gaps exist between student perceptions of importance (expectations) and performance of the university brand equity dimensions. The results show an existence of gaps for both all core and supporting university brand equity dimensions, indicating that student expectations are not met, which could have significant implications for creating a strong university brand. For example, university reputation had the largest gap, which the reputation could be improved through strengthening brand awareness, brand associations, brand loyalty, perceived quality, learning environment, brand trust, and emotional environment. Of the supporting factors, residence hall had the largest gap, suggesting a need to improve on residence halls, as well as physical facilities, dining services and library services, especially, residence halls and dining services are important to students living on campus and especially to female students.

\section{Discussion and Conclusion}

As stated above, the results of both studies (Pinar et al., 2020; Girard and Pinar, 2020a) show that universities include various sub-brands as complex systems that require university administrators to consider all relevant university brand equity dimensions in a holistic perspective (HemsleyBrown and Goonawardana, 2007; Rauschnabel et al., 2016) in a brand ecosystem framework (Pinar et al., 2011), which show their direct and indirect relationships. Therefore, it is essential to have a holistic approach to examining university brand equity to understand and capture the complex bundles of benefits, most notably academic and social benefits (Palmer et al., 2016) in creating a strong university brand and brand equity. The findings from a study by Girard and Pinar (2020a) confirm the importance of the supporting dimensions for properly functioning of the core dimensions ( $\mathrm{Ng}$ and Forbes (2009). Both studies indicate that Brand loyalty is the dependent variable in the model of both studies, confirming as one of requirements for strong brands, and influenced directly and indirectly by BE dimensions. In addition, Brand awareness is an important factor for creating a strong university brand and brand equity as it directly and/or indirectly influences the other brand equity dimensions, which is consistent with the brand equity conceptualization (Aaker, 1991, 1996, Keller, 1993, 2013). While higher education institutions could utilize social media to increase awareness and build university brand (i.e., Belanger et al., 2014; Pringle and Fritz, 2019), they should avoid any deceptive communications, as it erodes the brand equity of these institutions in the long run (Joyvice et al., 2019).

Perceived quality as measured with all faculty items was the critical role of faculty with students' learning experience and emphasizes their importance for university branding. This is consistent with prior research (i.e., Cheng and Tam, 1997; Aggarwal-Sharma et al., 2013) that highlighted the relationship between the students, faculty, and staff as one of the main determinants of the university reputation and its image. Also, while in a study by Girard and Pinar (2020a), 
emotional environment influences brand loyalty through brand trust, this was not the case in Pinar et al. (2020) study that the emotional environment does not have any influence on brand loyalty, which is interesting for understanding cross-cultural differences. Given the importance of emotion for developing a strong university brand and brand equity, is the university administrators in Turkey should develop strategies to create a strong emotional bond between university and students based on the desired learning experience in co-creation process (Dollinger et al., 2018), and positive experiences with their peers during social life of the campus (Gibson, 2010).

These empirical studies provide some insights about the core and supporting university brand equity dimensions, and their direct and indirect complex relations that could be beneficial for university administrators in creating a strong university brand and brand equity. However, the authors suggest that a caution must be exercised when interpreted the findings of their studies with their limitations. Despite above limitations, however, they state that university administrators can benefit from the findings of the empirical studies and a gap analysis in making both strategic and operational decisions for creating a strong university brand.

\section{References}

Aaker, D. (1991), Managing Brand Equity. Free-Press, New York, NY.

Aaker, David (1996), Building Strong Brands. Free-Press, New York, NY

Aggarwal-Sharma, A., Rao, V.R., and Popli, S. (2013), "Measuring consumer-based brand equity for Indian business schools", Journal of Marketing for Higher Education, Vol. 23, No.2, pp. 175-203. Doi: 10.1080/08841241.2013.866609

Ambler, T., Bhattacharya, C. B., Edell, J., Keller, K. L., Lemon, K. N., and Mittal, V. (2002), “Relating brand and customer perspectives on marketing management," Journal of Services Research, Vol. 5, No. 1, pp. 13-25.

Belanger, C., Bali, S., and Longden, B. (2014), "How Canadian universities use social media to brand themselves", Tertiary Education and Management, Vol. 20, No. 1, pp. 14-29.

Cheng, Y. C., \& Tam, W. M. (1997). Multi-models of quality in education. Quality assurance in

Education, Vol. 5 No. 1, pp. 22-31.

Dollinger, M. Lode, J., and Coastes, H. (2018), "Co-creation in higher education: Towards a conceptual model", Journal of Marketing for Higher Education, Vol. 28, No. 2, pp. 210-231.

Gibson, A. (2010), "Measuring business student satisfaction: a review and summary of the major predictors", Journal of Higher Education Policy and Management, Vol. 32, No. 3, pp. 251-259.

Girard, T. and Pinar, M. (2020a), "An empirical study of the dynamic relationships between the core and supporting brand equity dimensions in higher education", Journal of Applied Research in Higher Education, Vol. ahead-of-print No. ahead-of-print. https:/ / doi.org/10.1108/JARHE-042020-0097

Girard, T., Pinar, M. (2020b), Importance-Performance Gap Analysis of the University Brand Equity Dimensions, the Atlantic Marketing Association 2020 Virtual Conference (Competitive Track), October 2.

Hemsley-Brown, J. and Goonawardana, S S. (2007), “Brand harmonization in the international higher education market", Journal of Business Research, Vol. 60, No. 9, pp. 942-948.

Joyvice, C., Atemnkeng, J. T., Sama, M. C., Mbu, S. A., \& Neba, N. B. (2019), “The effect of deceptive marketing communication on the brand equity of private higher education institutions (PHEI's) in the Northwest and Southwest Regions of Cameroon", International Journal of Social and Administrative Sciences, Vol. 4, No.1, pp. 1-13.

Keller, K. L. (1993), "Conceptualizing, measuring and managing customer-based brand equity", Journal of Marketing, Vol. 57, No. 1, pp. 1-22.

Keller, K. L. (2013), Strategic Brand Management: Building, Measuring, and Managing Brand Equity, 4th ed. Prentice-Hall, Upper Saddle River, NJ.

Kotler, P. and Armstrong, G. (2012), Principles of Marketing. 13th ed., Prentice-Hall, Upper Saddle River, NJ. 
Md Noor, S., Manan, K. A., \& Kuthoos, H. M. A. (2019), “Assessing corporate brand equity of public universities", Jurnal Komunikasi: Malaysian Journal of Communication, Vol 35, No. 3, pp. 283299.

Ng, I.C. L. and Forbes, J. (2009), “Education as service: The understanding of university experience through the service logic", Journal of Marketing for Higher Education, Vol. 19, No. 1, pp. 38-64.

Nguyen, B., X. Yu, Melewar, T.C. and Hemsley-Brown, J. (2016), "Brand ambidexterity and commitment in higher education: An exploratory study", Journal of Business Research, Vol. 69, No. 8, pp. 3105-3112.

Oh, T.T., Keller, K.K., Neslin, S.A., Reibstein, D.J., and Lehmann, D.R. (2020), “The past, present, and future of brand research", Marketing Letters, published online (June 04), https://doi.org/10.1007/s11002-020-09524-w.

Palmer, A., Koenig-Lewis, N., and Asaad, Y. (2016), “Brand identification in higher education: A conditional process analysis", Journal of Business Research, Vol. 69, No. 8, pp. 3033-3040.

Pinar, M. and Trapp, P. (2008), "Creating competitive advantage through ingredient branding and brand-ecosystem: The case of Turkish cotton and textiles", Journal of International Food \& Agribusiness Marketing, Vol. 20, No. 1, pp. 29-56.

Pinar, M, Trapp, P., Girard, T., and Boyt, T. E. (2011). “Utilizing brand-ecosystem for branding and building brand equity in higher-education", International Journal of Educational Management, Vol. 25, No. 7, pp. 724-739.

Pinar, M, Trapp, P., Girard, T., and Boyt, T. E. (2014), “University brand equity: An empirical investigation of its dimensions", International Journal of Educational Management, Vol. 28, No. 6, pp. 616-634. https:// doi.org/10.1108/IJEM-04-2013-0051

Pinar, M., Girard, T., and Basfirinci, C. (2020), "Examining the relationship between brand equity dimensions and university brand equity: An empirical study in Turkey", International Journal of Educational Management, Vol. 34, No. 7, (forth coming). https://doi.org/10.1108/IJEM-082019-0313

Pringle, J. and Fritz, S. (2019), “The university brand and social media: using data analytics to assess brand authenticity", Journal of Marketing for Higher Education, Vol. 29, No. 1, pp. 19-44. DOI: 10.1080/08841241.2018.1486345.

Rauschnabel, P. A., Krey, N., Babin, B. J., and Ivens, B. S. (2016), "Brand management in higher education: The university brand personality scale", Journal of Business Research, Vol. 69 No. 8, pp. 3077-3086.

Rosenbaum-Elliott, R., Percy, L., and Pervan, S. (2011), Strategic Brand Management, 2nd ed. Oxford University Press, Oxford, UK.

Sultan, P. and Wong, H. Y. (2014), "An integrated-process model of service quality, institutional brand and behavioural intentions: The case of a university", Managing Service Quality: An International Journal, Vol. 24, No. 5, pp. 487-521.

Whisman, R. (2009), "Internal branding: A university's most valuable intangible asset", Journal of Product and Brand Management, Vol. 18, No. 5, pp. 367-370.

Wilson, E.J. and Elliot, E. A. (2016)." Brand meaning in higher education: Leaving the shallows via deep metaphors", Journal of Business Research, Vol. 69, No. 8, pp. 3058-3068. 